Research Paper

\title{
Promoter hypermethylation of early B cell factor 1 (EBF1) is associated with cholangiocarcinoma progression
}

\author{
Napat Armartmuntree1,2, Apinya Jusakul2,3, Chadamas Sakonsinsiri1,2, Watcharin Loilome1,2, Somchai \\ Pinlaor 2,4, Piti Ungarreevittaya ${ }^{2,5}$, Chern Han Yong6, Anchalee Techasen 2,3, Kanokwan Imtawil', Ratthaphol \\ Kraiklang7, Nattawan Suwannakul ${ }^{8}$, Waleeporn Kaewlert ${ }^{1,2}$, Timpika Chaiprasert ${ }^{1,2}$, Raynoo Thanan ${ }^{1,2}$ \\ and Mariko Murata ${ }^{\circledR}$ \\ 1. Department of Biochemistry, Faculty of Medicine, Khon Kaen University, Khon Kaen 40002, Thailand. \\ 2. Cholangiocarcinoma Research Institute, Khon Kaen University, Khon Kaen 40002, Thailand. \\ 3. Faculty of Associated Medical Sciences, Khon Kaen University, Khon Kaen 40002, Thailand. \\ 4. Department of Parasitology, Faculty of Medicine, Khon Kaen University, Khon Kaen 40002, Thailand \\ 5. Department of Pathology, Faculty of Medicine, Khon Kaen University, Khon Kaen 40002, Thailand. \\ 6. Laboratory of Cancer Epigenome, Division of Medical Science, National Cancer Center Singapore, Singapore. \\ 7. Faculty of Public Health, Khon Kaen University, Khon Kaen 40002, Thailand. \\ 8. Department of Environmental and Molecular Medicine, Mie University Graduate School of Medicine, Mie 514-8507, Japan.
}

$\square$ Corresponding authors: Dr. Raynoo Thanan, Department of Biochemistry, Faculty of Medicine, Khon Kaen University, Khon Kaen 40002, Thailand. Tel/Fax: 6643348 386; E-mail: raynoo@kku.ac.th; Professor Mariko Murata, Department of Environmental and Molecular Medicine, Mie University Graduate School of Medicine, Mie 514-8507, Japan. Tel/Fax: +81-59-231-5011; E-mail: mmurata@doc.medic.mie-u.ac.jp.

() The author(s). This is an open access article distributed under the terms of the Creative Commons Attribution License (https://creativecommons.org/licenses/by/4.0/). See http://ivyspring.com/terms for full terms and conditions.

Received: 2020.08.25; Accepted: 2021.02.14; Published: 2021.03.05

\begin{abstract}
DNA hypermethylation in a promoter region causes gene silencing via epigenetic changes. We have previously reported that early $B$ cell factor 1 (EBFl) was down-regulated in cholangiocarcinoma (CCA) tissues and related to tumor progression. Thus, we hypothesized that the DNA hypermethylation of EBF1 promoter would suppress EBF1 expression in CCA and induce its progression. In this study, the DNA methylation status of EBF1 and mRNA expression levels were analyzed in CCA and normal bile duct (NBD) tissues using a publicly available database of genome-wide association data. The results showed that the DNA methylation of EBF1 promoter region was significantly increased in CCA tissues compared with those of NBD. The degree of methylation was negatively correlated with EBFI mRNA expression levels. Using methylation-specific PCR technique, the DNA methylation rates of EBFI promoter region were investigated in CCA tissues $(n=72)$. CCA patients with high methylation rates of EBF1 promoter region in the tumor tissues (54/72) had a poor prognosis. Higher methylation rates of EBFl promoter region have shown in all CCA cell lines than that of an immortal cholangiocyte cell line (MMNK1). Upon treatment with the DNA methyltransferase inhibitor 5-Aza-dC, increased EBF1 expression levels and reduced DNA methylation rates were observed in CCA cells. Moreover, restoration of EBFI expression in CCA cells led to inhibition of cell growth, migration and invasion. In addition, RNA sequencing analysis suggested that EBF1 is involved in suppression of numerous pathways in cancer. Taken together, DNA hypermethylation in the EBFI promoter region suppresses EBFI expression and induces CCA progression with aggressive clinical outcomes.
\end{abstract}

Key words: cholangiocarcinoma; DNA methylation; EBF1; tumor progression; epigenetics

\section{Introduction}

Epigenetics is a process that affects gene activity and expression without any changes in DNA sequences or genotype. Epigenetic processes include DNA methylation, histone modification and RNAdirected DNA methylation [1, 2]. DNA methylation and histone modification are mostly observed in all organisms, whereas RNA-directed DNA methylation is found in plants. Histone modification and DNA methylation exert synergetic epigenetic regulatory effects [3]. Therefore, DNA methylation is an epigenetic marker and plays a key role in carcinogenesis [4]. This process is catalyzed by DNA 
methyltransferases (DNMTs), which transfer a methyl group from $\mathrm{S}$-adenosylmethionine to a cytosine nucleotide molecule in regions known as $\mathrm{CpG}$ sites or CpG islands [5]. In general, DNA hypermethylation of CpG islands which are located in a promoter region of gene causes silencing of the corresponding gene, whereas DNA hypomethylation at promoter regions promotes gene expression. DNA hypermethylation of promoter regions of many tumor suppressor genes suppresses their related gene expression and induces carcinogenesis [6].

Early B cell factor 1 (EBF1) is a transcriptional factor playing important roles in the differentiation of multiple stem cell lineages into mature cells [7-9]. EBF1 is a tumor suppressor in leukemia [10], breast cancer [11] and cholangiocarcinoma (CCA) [12]. EBF1 suppression is mediated via different mechanisms such as genomic loss in breast cancer [11], point mutation in pancreatic ductal adenocarcinoma [13], overexpression of EBF1 inhibitors (ZNF423 and ZNF521) in many cancers, such as CCA [14], acute lymphoblastic leukemia [15] and nasopharyngeal carcinoma [16], and aberrant expression of microRNAs targeting EBF1 in white adipose tissues [17]. However, little is known about the importance of epigenetic changes in suppression of EBF1 expression.

CCA, a cancer arising from biliary epithelial cells, is the most common form of cancer in the Northeast region of Thailand including Khon Kaen Province where Opisthorchis viverrini (O. viverrini) infection is highly endemic [18]. This small liver fluke has been classified as a major cause of CCA (group 1 carcinogen) by the International Agency for Research on Cancer [19]. Several studies have strongly supported that oxidative stress was induced by $O$. viverrini-mediated inflammation. Oxidative stress is a major CCA driver and associated with biological damages, genetic instability, bile duct cell proliferation and pathological change in bile duct epithelium [19-22]. When cholangiocyte cell lines were treated with hydrogen peroxide for a long-term, they increased cancer cell properties such as high expression levels of antioxidant enzymes (e.g., catalase (CAT), superoxide dismutase-2 (SOD2)) and high cell proliferation rates compared to the parental cells. Moreover, oxidative stress induces epigenetic changes through induction of the expression of DNMT1 [23]. The downregulation of EBF1 expression has recently been investigated in CCA patient tissues and it induced tumorigenic and stem cell properties of the cholangiocyte cells (MMNK1) [12]. According to the previous findings, $47 \%$ of CCA tissues had EBF1 downregulation and increased oxidative stress marker. Furthermore, chronic exposure of cholangiocyte cells to oxidative stress could inhibit
EBF1 expression, suggesting that prolonged oxidative stress could inhibit EBF1 expression [12]. However, it should be noted that $53 \%$ of EBF1 downregulation in CCA tissues were not related to oxidative stress [12]. In the present study, we hypothesized that the downregulation of EBF1 expression was not only resulted from oxidative stress, but also from the DNA hypermethylation of the EBF1 promoter of CCA cells, that may lead to CCA progression with aggressive clinical outcomes.

Here, we aimed to analyze the DNA methylation patterns and mRNA expression levels of EBF1 gene using the online data downloaded from the NCBI Gene Expression Omnibus (GEO) database (accession number GSE89803) [24]. The significance of DNA methylation status of EBF1 promoter region of CCA tissues, CCA cell lines, and an immortalized cholangiocyte cell line (MMNK1) was confirmed using methylation-specific polymerase chain reaction (MSP) analysis. Associations between DNA methylation status and clinicopathological data including age, sex, tumor stage, histological types, metastasis status and survival days after surgery were evaluated. Moreover, CCA cell lines and MMNK1 cell line were treated with the DNMT inhibitor 5-Aza-dC and subjected to MSP and EBF1 expression analyses using real-time quantitative polymerase chain reaction (RT-qPCR) and immunocytochemistry (ICC) techniques to confirm that the EBF1 expression level of CCA is regulated by its promoter hypermethylation. To evaluate that the increase of EBF1 expression can be used for CCA targeted therapy, the functional roles of EBF1 related to tumor suppression were investigated further in EBF1-overexpressing CCA cells.

\section{Materials and Methods}

\section{Human CCA tissues}

All frozen tissues and paraffin-embedded tissues from the CCA patients were obtained from the specimen bank of the Cholangiocarcinoma Research Institute, Khon Kaen University, Thailand. CCA tissues and normal bile ducts from tumor adjacent areas were collected from the patients that were admitted at the surgical wards of Srinagarind Hospital, Khon Kaen University. The study was approved by the Ethic Committee for Human Research, Khon Kaen University, Thailand (HE571283 and HE611577).

\section{Illumina $450 \mathrm{~K}$ data methylation analysis}

Illumina Infinium Human Methylation 450K Methylation data (138 CCA tissues and 4 normal bile duct samples) were downloaded from the NCBI GEO database (accession number GSE89803). Data were 
subjected to pre-processing using the "minfi" [25] and "wateRmelon" [26] R packages. Methylation levels of CpG sites were calculated as $\beta$-values. $\beta$-value is a continuous variable between 0 and 1 and a value of 0 corresponds to no methylation, while a value of 1 corresponds to $100 \%$ methylation at the specific CpG site analyzed. Fifty-six probes proximal to EBF1 were tested for methylation levels between normal bile duct and CCA samples (Figure 1A). Annotations of $\mathrm{CpG}$ probes to genomic features were obtained from the "Illumina Human Methylation 450K manifest" package $[25,26]$. Probes annotated to the transcription start site (TSS) 1500 or first exon of EBF1 were considered the promoter probes, while the remainder (annotated to gene body and 3' UTR) were considered non-promoter probes, giving 11 promoter probes and 45 non-promoter probes. A probe was considered hypermethylated if the difference in mean beta values between the two groups was at least 0.2, and FDR < 0.05 (two-sided $\mathrm{t}$ test, with Benjamini-Hochberg correction for multiple hypothesis testing).

\section{DNA extraction}

Genomic DNA was extracted from frozen human CCA tissues $(\mathrm{n}=72)$ and cell pellets, as previously described with some modifications [27]. Frozen tissues $(50 \mathrm{mg})$ or cell pellets $\left(10^{6}\right.$ cells $)$ were homogenized in a lysis solution $(1 \%[\mathrm{w} / \mathrm{v}]$ Triton $\mathrm{X}-100,0.32 \mathrm{M}$ saccharose, $5 \mathrm{mM}$ magnesium chloride $\left[\mathrm{MgCl}_{2}\right]$, and $10 \mathrm{mM}$ Tris- $\left.\mathrm{HCl} \mathrm{pH} 7.5\right)$ and centrifuged at $10,000 \times \mathrm{g}$ for $5 \mathrm{~min}$. The pellets were collected and repeatedly washed, followed by incubation with $8 \mu \mathrm{L}$ of RNase A $(1 \mathrm{mg} / \mathrm{mL})$ and $200 \mu \mathrm{L}$ of enzyme reaction solution $(1 \%[\mathrm{w} / \mathrm{v}]$ sodium dodecyl sulfate [SDS], 5 $\mathrm{mM}$ ethylenediaminetetraacetic acid [EDTA], and 10 $\mathrm{mM}$ Tris- $\mathrm{HCl}, \mathrm{pH} 8.0$ ) for $20 \mathrm{~min}$. The samples were treated with $10 \mu \mathrm{L}$ of proteinase $\mathrm{K}(17 \mathrm{mg} / \mathrm{mL})$ at 37 ${ }^{\circ} \mathrm{C}$ for $3 \mathrm{~h}$ with occasional mixing. After incubation, $300 \mu \mathrm{L}$ of $7.6 \mathrm{M}$ sodium iodide (NaI) solution was added to the mixture, followed by the addition of 500 $\mu \mathrm{L}$ of absolute isopropanol. The mixture was centrifuged at 10,000 $\times \mathrm{g}$ for $10 \mathrm{~min}$ and the extracted DNA pellet was washed with $40 \%$ isopropanol. The pellet was washed twice with $70 \%$ ethanol and re-suspended in Tris-EDTA buffer ( $\mathrm{pH}$ 8.0). The DNA solution was stored at $-20{ }^{\circ} \mathrm{C}$ until analysis. DNA concentration and purity were determined with NanoVue ${ }^{\mathrm{TM}}$ spectrophotometer (GE Healthcare, NJ, USA).

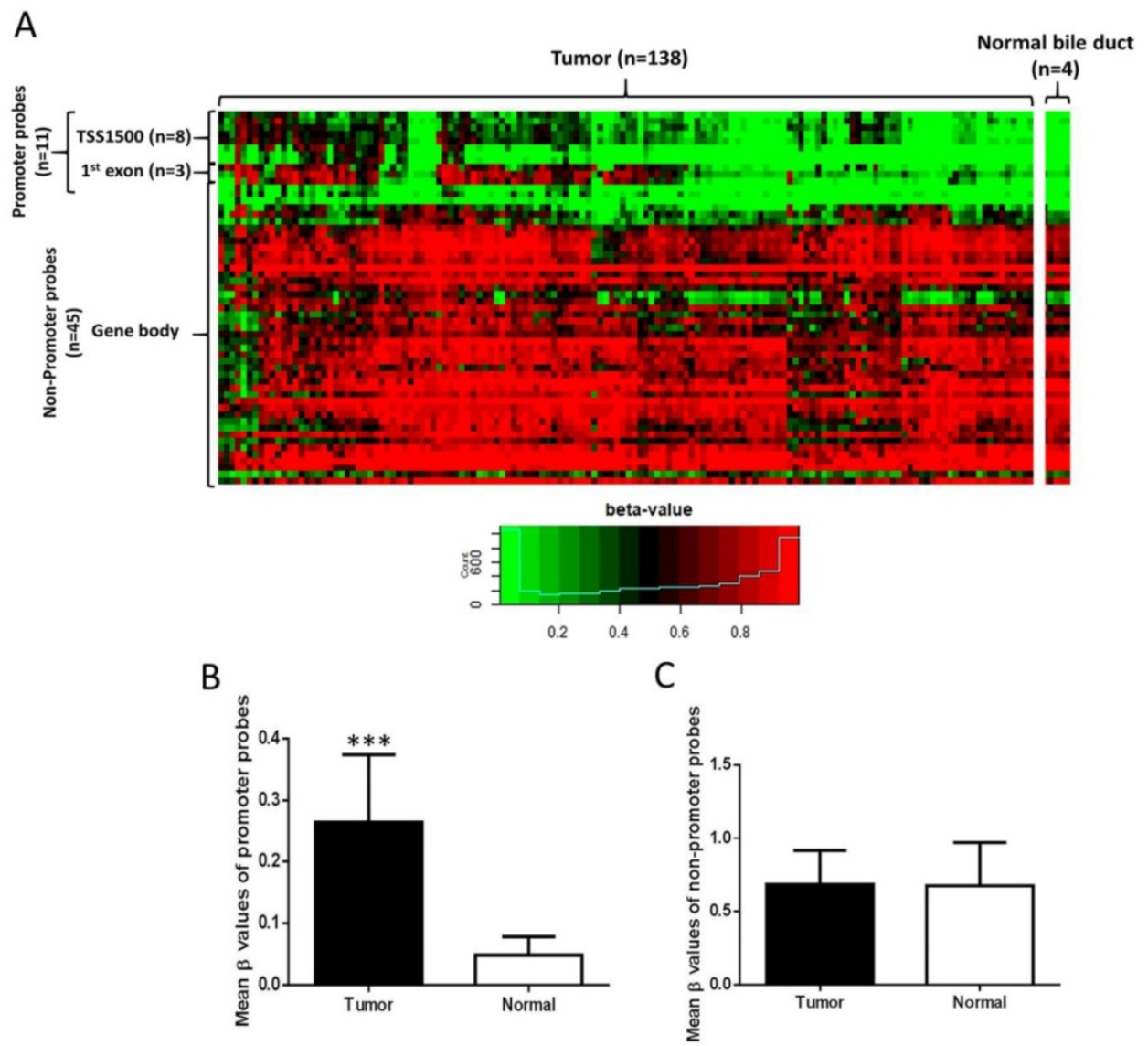

Figure 1. Distribution of EBF1 methylation in CCA. (A) Heat map of all EBF1 methylated probes. Hierarchical clustering was performed using all methylated EBF1 probes. TSS1500 covers -200 to -1500 nt upstream of translation start site (TSS). Box plots illustrated the methylation $\beta$-values between normal bile duct (Normal) and CCA tissue (Tumor) of the EBFI promoter region (B) and non-promoter region (C). Statistically significant differences $(* * * p<0.0001)$ in group $\beta$-values by two-sided t-test. 


\section{Bisulfite conversion of genomic DNA}

Genomic DNA was subjected to bisulfite conversion using EZ DNA Methylation-Gold ${ }^{\mathrm{TM}}$ Kit (Zymo Research, CA, USA) according to the manufacturer's instructions. In brief, $130 \mu \mathrm{L}$ of CT conversion reagent was added to $1 \mu \mathrm{g}$ of DNA in a total volume of $20 \mu \mathrm{L}$ in a $200-\mu \mathrm{L}$ microtube. Bisulfite conversion was performed as follows: incubation of samples at $98^{\circ} \mathrm{C}$ for $10 \mathrm{~min}$, followed by $64^{\circ} \mathrm{C}$ for 2.5 h. The bisulfite-treated DNA was washed and eluted as per the manufacturer's protocol. The treated samples were stored at $-20{ }^{\circ} \mathrm{C}$ until analysis. Bisulfite-treated DNA samples were subjected to PCR using calponin-specific primers for the confirmation of their complete bisulfite-mediated conversion [28].

\section{Methylation-specific polymerase chain reaction (MSP) analysis}

EBF1 methylation rates were determined using a MSP assay. Bisulfite-treated DNA samples were used as templates. The methylation primers $(\mathrm{M})$ and unmethylation primers (U) specific for amplification of EBF1 promoter region are shown in Table S1. Both primers were designed using The BiSearch web server $[29,30]$. The PCR reaction condition is shown in Table S2. Primer sets were designed to bind at the same region, and the PCR products were $142 \mathrm{bp}$ (Chr5:159100738-159100879, -821 to -963 bp upstream of EBF1 transcript start site) in length. PCR reactions were performed on C-1000 Thermal cycle (Bio-RAD, CA, USA) and the products were separated on $1.5 \%$ agarose gel, stained with ethidium bromide, and visualized under UV illumination (Bio-Rad, CA, USA). The products (142 bp) were subjected to DNA sequencing (Pacific Science Company, WA, USA). The $142 \mathrm{bp}$ PCR products showed a 100\% match with the designed bisulfite-treated DNA sequences (methylated and unmethylated products; Supplementary Figure S1). Methylation patterns of KKU-213B and MMNK1 were used as inter-batch controls. The quantification of $142 \mathrm{bp}$ band intensity was performed with ImageJ software version 1.47. Methylation rate $(\mathrm{M} /[\mathrm{M}+\mathrm{U}])$ was calculated from the intensities of PCR products of $\mathrm{M}$ and $\mathrm{U}$ primers in each case.

\section{Cell lines}

Human CCA cell lines, including KKU-213A, KKU-213B and KKU-213C were obtained from the Cholangiocarcinoma Research Institute, Khon Kaen University, Thailand. An immortalized cholangiocyte cell line (MMNK1) was obtained from Okayama University, Japan [31]. KKU-213A, KKU-213B and KKU-213C have been recently characterized and renamed from KKU-213, KKU-214 and KKU-156, respectively [32]. All cell lines were cultured in Ham's F12 medium (Invitrogen, MA, USA) supplemented with $10 \%$ fetal calf serum, $100 \mathrm{U} / \mathrm{mL}$ of penicillin, and $100 \mu \mathrm{g} / \mathrm{mL}$ of streptomycin (complete media) at $37^{\circ} \mathrm{C}$ in a humidified incubator maintained in an atmosphere of $5 \% \mathrm{CO}_{2}$. Cells were subcultured once they reached confluency and media were changed once every 2 to 3 days.

\section{Treatment of cells with 5-aza-2'-deoxycytidine (5-Aza-dC)}

The 5-Aza-dC (Sigma-Aldrich, MO, USA) was dissolved in $100 \%$ dimethyl sulfoxide (DMSO) to obtain a $200 \mathrm{mM}$ stock solution, aliquoted and stored at $-20{ }^{\circ} \mathrm{C}$ until analysis. CCA and MMNK1 cell lines were seeded $\left(2 \times 10^{5}\right.$ cells $\left./ \mathrm{mL}\right)$ in $100 \times 20 \mathrm{~mm}$ cell culture dishes and continuously treated with $1 \mu \mathrm{M}$ of 5-Aza-dC containing $0.05 \%$ DMSO in complete medium (10 mL) for 6-12 days. The cells were harvested for MSP, RT-qPCR and ICC techniques. In addition, cells treated with $0.05 \%$ DMSO in complete medium without 5-Aza-dC were used as controls.

\section{Transient overexpression of EBF I}

The EBF1 expression vector (EBF1 vector) and control vector (empty vector) were synthesized (Dharmacon Inc., Lafayette, CO, USA) and extracted from Escherichia coli (E. coli) cells containing a EBF1 vector (pLOC-TurboRFP containing EBF1 gene) or a control vector (pLOC-TurboRFP without EBF1 gene). Plasmid DNA extraction from E. coli was performed using GF-1 Plasmid DNA Extraction Kit (Vivantis Technologies, Selangor, Malaysia) following the manufacturer's instructions. KKU-213A cell line was maintained in complete media at $37{ }^{\circ} \mathrm{C}$ in a humidified incubator with $5 \% \mathrm{CO}_{2}$. Cells were seeded in six-well plates $\left(1.5 \times 10^{5}\right.$ cells/well $)$ and $70-80 \%$ confluent cells were transiently transfected with $1 \mu \mathrm{g}$ of control vector or EBF1 vector using Lipofectamine 2000 (Invitrogen, MA, USA) according to the manufacturer's recommendations. Twenty-four hours after transfection, cells were collected for various experiments. Cells transfected with control vector served as control cells.

\section{Detection of mRNA levels by RT-qPCR}

Trizol ${ }^{\circledR}$ reagent (Invitrogen, MA, USA) was used to extract total RNA from cell pellets as per the manufacturer's protocol. For cDNA synthesis, $2 \mu \mathrm{g}$ of total RNA was converted to cDNA using HighCapacity cDNA Reverse Transcription Kit (Applied Biosystems, CA, USA). EBF1, $\beta$-actin, IL-6, COX-2, MMP-9, Oct3/4, CAT, SOD2 mRNA expression levels were analyzed with TaqMan gene expression assay using TaqMan probes (EBF1, Hs00395513_m1; $\beta$-actin, 
Hs99999903_m1; IL-6, Hs00174131_m1; COX-2, Hs00153133_m1; MMP-9, Hs00957562_m1; Oct3/4, Hs04260367_gH; CAT, Hs00156308_m1 and SOD2, Hs01553554_m1) on ABI-7500 RT-qPCR system (Applied Biosystems, CA, USA). Relative mRNA expression (fold change) was analyzed with a cycle threshold $(\mathrm{Ct})$ in a linear range of amplification with $\beta$-actin as an internal control.

\section{Immunofluorescence staining}

CCA cells and transient CCA cells $(50,000$ cells/well) were seeded in eight-well chamber slide for overnight cultivation. The cells were fixed with $4 \%$ formaldehyde-containing phosphate-buffered saline (PBS) for $10 \mathrm{~min}$ at room temperature. Cells were incubated in $0.5 \%(\mathrm{v} / \mathrm{v})$ Triton X-100 solution to change their membrane permeability, followed by incubation with $2 \mathrm{~N}$ hydrochloric acid $(\mathrm{HCl})(30 \mathrm{~min})$ for antigen retrieval. Nonspecific binding was blocked using 1\% (w/v) skim milk in PBS for $30 \mathrm{~min}$. Cells were incubated with $5 \mu \mathrm{g} / \mathrm{mL}$ of rabbit anti-EBF1 polyclonal antibody (Abcam, MA, USA) at room temperature for overnight, followed by treatment with Alexa Fluor ${ }^{\circledR} 59$ goat anti-rabbit IgG (Invitrogen, MA, USA). Nucleus was staining with DAPI Fluoromount-G ${ }^{\circledR}$ (Southern Biotech, Alabama, USA). The stained cells were analyzed using a fluorescent microscope (Olympus BX53F, Tokyo, Japan).

\section{Immunocytochemistry of cell lines}

Cells (60,000 cells/well) were seeded in 48-well plates for overnight cultivation. The cells were fixed with $4 \%$ paraformaldehyde-containing phosphate-buffered saline (PBS) for $30 \mathrm{~min}$ at room temperature. Cells were incubated in $0.2 \%(\mathrm{v} / \mathrm{v})$ Triton X-100 solution to change their membrane permeability, followed by incubation with PBS containing $0.3 \%(\mathrm{v} / \mathrm{v})$ hydrogen peroxide $(30 \mathrm{~min})$. Nonspecific binding was blocked using 3\% (w/v) bovine serum albumin (BSA) in PBS for $30 \mathrm{~min}$. Cells were incubated with $3 \mu \mathrm{g} / \mathrm{mL}$ of rabbit anti-EBF1 polyclonal antibody (Abcam, MA, USA) at room temperature for overnight, followed by treatment with peroxidase-conjugated Envision ${ }^{\mathrm{TM}}$ secondary antibody (DAKO, Glostrup, Denmark). The color was developed with 3,3'-diaminobenzidine tetrahydrochloride (DAB) substrate kit (Vector Laboratories, Inc., CA, USA) and washed with distilled water. The stained cells were dehydrated with ethanol and air dried for overnight. The stained cells were analyzed using an inverted microscope. The semi-quantitative analysis was calculated in ImageJ Fiji software using the method described by Crowe and Yue [33].

\section{Wound healing assay}

Cells were seeded in a 24-well plate and cultured in complete medium at $37{ }^{\circ} \mathrm{C}$ in a humidified incubator maintained in an atmosphere of $5 \% \mathrm{CO}_{2}$. After reaching $\sim 90 \%$ confluence, cell monolayers were scratched using a $200-\mu \mathrm{L}$ pipette tip and rinsed thrice with PBS to remove cell debris. Cell migration in the wound area was observed under a phase-contrast microscope and digitally photographed. Wound healing was measured using images and the migration area was calculated from the results of the area of original wound minus the area of wound during healing divided by the area of original wound.

\section{Cell invasion assay}

The invasive ability of cells was assessed using Boyden chamber with an insert filter coated with Matrigel Matrix coating solution $(8-\mu \mathrm{m}$ pore size; Corning, NY, USA). The assay kit was reconstituted by adding serum-free medium into the upper chamber and complete medium into the lower chamber for approximately $1 \mathrm{~h}$. Before seeding the cells, serum-free medium in the upper chamber was removed and replaced with cells $\left(3 \times 10^{4}\right.$ cells $)$ in serum-free medium. After $24 \mathrm{~h}$ incubation, the non-invading cells in the upper chamber were removed with a cotton swab. The invaded cells attached under the filter were fixed with $100 \%$ methanol for $30 \mathrm{~min}$ and stained with hematoxylin for overnight. The quantification of invading cells was performed by counting six random fields at $\times 200$ magnification under a light microscope.

\section{Hydrogen peroxide $\left(\mathrm{H}_{2} \mathrm{O}_{2}\right)$ treatment and Sulforhodamine B (SRB) assay}

For $\mathrm{H}_{2} \mathrm{O}_{2}$ exposure, cells $\left(3 \times 10^{3}\right.$ cells/well in 100 $\mu \mathrm{L}$ volume) were plated into 96-well plates in triplicate, after $12 \mathrm{~h}$ of cell adhesion, the cells were exposed to different concentrantion of $\mathrm{H}_{2} \mathrm{O}_{2}$ (Sigma-Aldrich, MO, USA) for $72 \mathrm{~h}$. The cells were then fixed with $10 \%(\mathrm{w} / \mathrm{v})$ trichloroacetic acid (TCA) and subjected to cell density analysis using SRB colorimetric assay. The cells were dried at $60^{\circ} \mathrm{C}$ for 30 min and treated with SRB $(0.4 \%[\mathrm{w} / \mathrm{v}]$ in $1 \%[\mathrm{v} / \mathrm{v}]$ of acetic acid) and incubated for $1 \mathrm{~h}$. Excess dye was removed by repeatedly washing with $1 \%(\mathrm{v} / \mathrm{v})$ acetic acid. The protein-bound dye was dissolved in $10 \mathrm{mM}$ of Tris-based solution ( $\mathrm{pH}$ 10.5) for $1 \mathrm{~h}$ with gentle shaking. The optical density (OD) was spectrophotometrically determined at $540 \mathrm{~nm}$ wavelength using a microplate reader (Sunrise, Tecan Austria $\mathrm{GmbH})$. 


\section{RNA sequencing (RNA-seq) and data processing}

NucleoSpin ${ }^{\circledR}$ RNA kit was used to extract the total RNA from KKU-213A cells treated with empty vector (control cells; $n=2$ ) or EBF1 plasmid vector (EBF1-overexpressing cells; $n=2$ ). All obtained RNA samples were subjected to NovaSeq 6000 Sequencing System at Takara Company (Shiga, Japan). For data processing pipeline, Genedata Profiler Genome software (version 11.0.11) was used for base calling. STAR (version 2.5.3a) was used to align RNA sequencing reads to reference genome. The RNA sequencing of EBF1-overexpressing CCA cells were uploaded to the NCBI GEO database (accession number GSE162836) and provided the processed RNA sequencing data as Supplementary Table S3. A $P$ value $<0.05$ was deemed as a significant differential gene expression. Fold-change (FC) was calculated by FPKM values of test group divided by FPKM values of control group. The FC $>1$ and FC $<1$ are used as cutoffs for up-regulated and down-regulated genes, respectively. The lists of up-regulated and down-regulated genes were submitted to DAVID Bioinformatics Resources version 6.8 online server (https://david.ncifcrf.gov) and KEGG pathway enrichment analysis.

\section{Statistical analysis}

Statistical analysis was performed using SPSS software version 17.0 (IBM Corporation, USA). The association of methylation status of EBF1 promoter with patient clinicopathological factors assessed by Fishers' exact test was analyzed. Survival analysis was performed using the Kaplan-Meier estimate with log-rank test. Levels of mRNA and protein expression were compared with the Student's t-test. The difference in the methylation levels between normal bile duct and CCA was analyzed using two-sided $\mathrm{t}$-test and Benjamini-Hochberg correction for multiple hypothesis testing, with FDR $<0.05$ considered statistically significant.

\section{Results}

\section{The methylation status and mRNA expression levels of EBF 1 in a publicly available genome- wide database}

The methylation status of EBF1 in a publicly available genome-wide DNA methylation database (GSE89803) of CCA and micro-disectioned normal bile ducts tissues from the $O$. viverrini infection edemic (Northeast Thailand) and non-endemic areas (Singapore and Romania) was investigated [24]. Methylation values of CpG sites proximal to EBF1 were compared between tumors $(n=138)$ and normal bile ducts $(n=4)$ (Figure 1A). Among 56 EBF1 probes, 11 of 11 probes located at EBF1 promoter region (TSS1500 and first exon) were significantly hypermethylated in CCA tumors compared with normal bile ducts (Figure 1B), and the methylation levels of 4 (located at TSS1500) of 11 probes were negatively correlated with the EBF1 mRNA expression levels as shown in Table S4. In contrast, the methylation levels of 45 non-promoter probes were not different between CCA and normal tissues (Figure 1C).

\section{Methylation status of EBF 1 in human CCA tissues based on the clinicopathological data}

To confirm the DNA methylation array of the EBF1 promoter, alteration in methylation status of EBF1 was studied using a MSP technique. The methylation rate $(\mathrm{M} /[\mathrm{M}+\mathrm{U}])$ was calculated from the intensities of the PCR products using a specific methylation primer set $(\mathrm{M})$ and an unmethylation primer set $(\mathrm{U})$. The methylation rates ranged from 0 to 1. Figure $2 \mathrm{~A}$ and $2 \mathrm{~B}$ illustrates an example of EBF1 methylation patterns in KKU-213B cell line, MMNK1 cell line, normal bile duct tissues and CCA tissues. The DNA methylation patterns of KKU-213B and MMNK1 cell lines were used as inter-batch controls. All normal bile ducts (NBD) tissues were positive with $U$ primers only and showed low EBF1 methylation rates at the promoter region (Figure 2A). Most of CCA tissues showed positive for both primer types ( $\mathrm{M}$ and $\mathrm{U}$ primers) except for few cases (as shown in case R026, Figure 2B) with $U$ primers positive only. Focus on the DNA methylation patterns of NBD and CCA tissues of the case number E74 in Figure $2 \mathrm{~A}$ and $2 \mathrm{~B}$, the $\mathrm{PCR}$ product of $\mathrm{M}$ primers was increased in CCA tissue compared to the individual normal bile duct tissue. The DNA methylation rates were significantly higher in CCA tissues (average methylation rate $=0.36 \pm 0.25)$ compared to the NBD (average methylation rate $=0.05 \pm 0.01$ ) as shown in Figure 2C.

Then, the quartile 1 (Q1) value $(0.08)$ of the methylation rates of CCA tissues was used as a cut-off point for low- and high-DNA methylation status. The results of correlation analyses between methylation status of EBF1 promoter region and the gender, age, CCA histology types, and metastatic stages of CCA patients showed no significant associations (Table S5). However, when association between methylation status of EBF1 promoter and survival analysis was determined with the Kaplan-Meier method and log-rank test, the patients with CCA exhibiting high EBF1 methylation status is associated with poor prognosis $(P=0.023)$, as shown in Figure $2 \mathrm{D}$. The overall median survival time was 256 days (95\% 
confidence interval [CI], 221.3-300.7). CCA patients with high EBF1 methylation status showed shorter survival (median, 243 days; 95\% CI, 219.3-266.7) than those with low EBF1 methylation status (median, 374 days; 95\% CI, 305.4-442.6).

\section{Methylation status and expression of EBF1 are regulated by DNMTs in CCA and cholangiocyte cells}

The methylation patterns of EBF1 promoter region of a cholangiocyte cell line (MMNK1) and CCA cell lines (KKU-213A, KKU-213C and KKU-213B) were examined. DNA methylation rates of the EBF1 promoter region of CCA cell lines (average methylation rate $=\mathrm{KKU} 213 \mathrm{~A}, 0.95 \pm 0.007 ; \mathrm{KKU} 213 \mathrm{C}$, $0.82 \pm 0.001$ and KKU213B, $0.97 \pm 0.005$ ) were significantly higher than that of the MMNK1 cell line (average methylation rate $=0.08 \pm 0.04$ ). To evaluate the importance of DNA methylation on EBF1 expression in the cholangiocyte and CCA cell lines,
MMNK1 and CCA cells were treated with DNMT inhibitor, 5-Aza-dC, for 6 days. After 5-Aza-dCtreatment, CCA cell lines (KKU-213A and KKU-213B) showed significant reduction of the DNA methylation rates as shown in Figure 3A and Figure 3B. Notably, significant increases of EBF1 mRNA expression were observed in 5-Aza-dC treated-KKU-213A and KKU-213B cells (Figure 3C). Such singificant changes were not observed in 5-Aza-dC treated-MMNK1 and KKU-213C cells under the condition used. Immunocytochemical technique revealed protein levels were similar to gene expression levels, as shown in Figure 3D and Figure 3E. Higher concentration of 5-Aza-dC $(5 \mu \mathrm{M})$ yieled significant increase of EBF1 mRNA expression in KKU-213C cells, but no change in MMNK1 cells (data not shown). These data suggest that induction of DNA methylation of EBF1 promoter results in EBF1 downregulation in CCA.
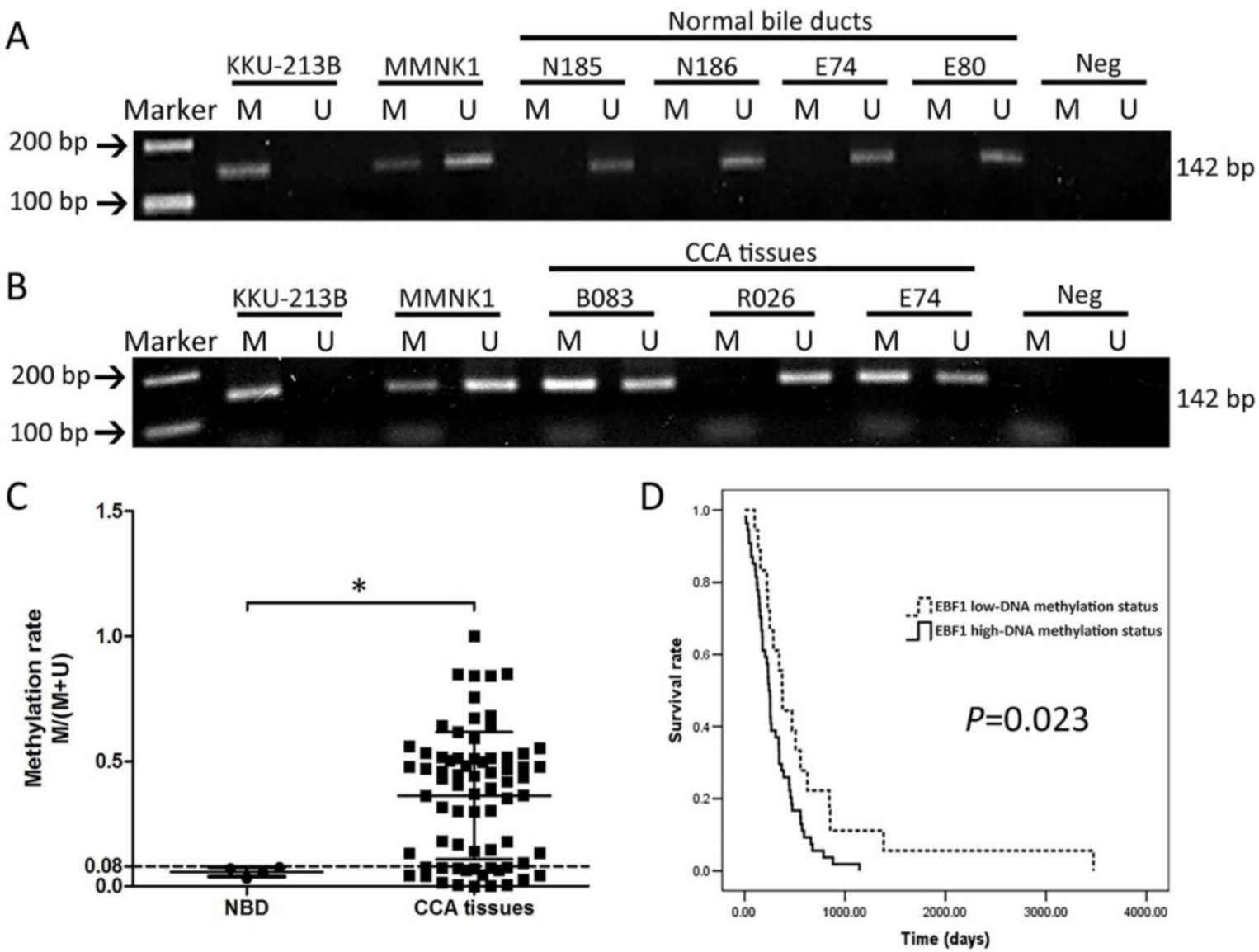

Figure 2. MSP analyses of EBF1 promoter region in normal bile ducts $(N B D)(A)$ and $C C A$ tumor tissues $(B)$. $M=P C R$ product from methylation primers, $U=P C R$ product from unmethylation primers. Methylation patterns of KKU-213B and MMNK1 cells were used as the inter-batch quality controls. $(C)$ Methylation rates $(M /[M+U])$ in $N B D(n=4)$ and CCA $(n=72)$ tissues. $P$ value was calculated with Mann-Whitney $U$ test $(* P=0.015)$. (D) Kaplan-Meier analyses of survival rates of patients with CCA with low-DNA methylation (methylation rate $\leq 0.08$; dashed line) and high DNA methylation (methylation rate $>0.08$; solid line) of EBF1 promoter regions. $P$ value was analyzed with log-rank test. 


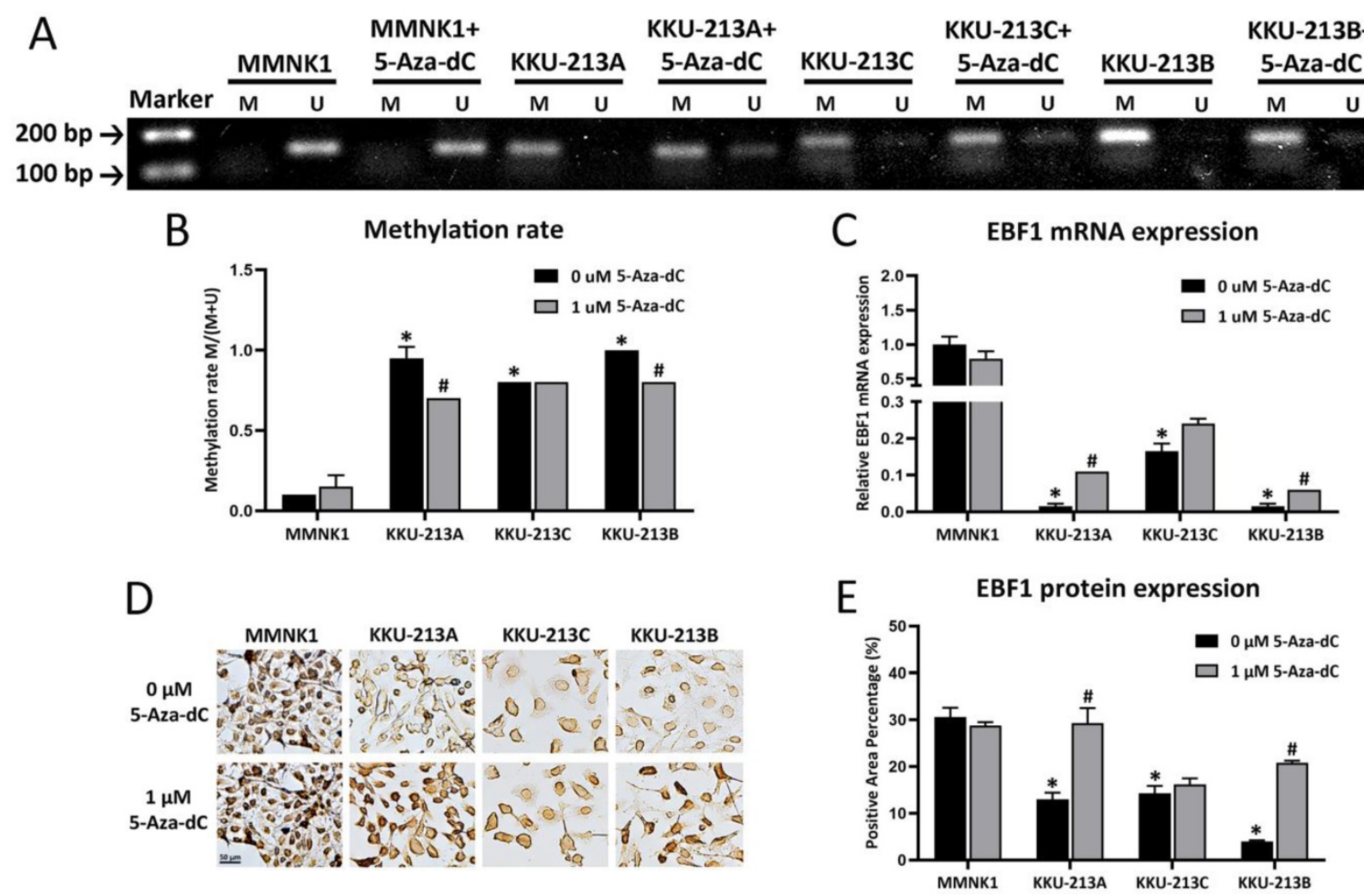

Figure 3. Effects of 5-Aza-dC treatment on DNA methylation status and expression of EBF1 (A) MSP analyses of EBF1 promoter region in an immortalized cholangiocyte (MMNK1) and CCA (KKU-213A, KKU-213C, KKU-213B) cell lines. $M=$ PCR product from methylation primers, $U=P C R$ product from unmethylation primers. (B) Graphical representation of the DNA methylation rates of MMNK1 and CCA cell lines. (C) mRNA expression levels of EBF1 in cells with or without 5 -Aza-dC treatment for 6 days (KKU-213A) and 12 days (MMNK1, KKU-213C and KKU-213B). (D) Protein expression levels and (E) semi-quantification of EBF1 expression was detected by immunocytochemical staining. $* P<0.05$ vs. MMNK1 cell; $\# P<0.05$ vs. 5 -Aza-dC untreated-CCA cells.

\section{Restored EBFI expression suppresses migration, proliferation, and invasion of CCA cells}

To see whether EBF1 overexpression can be used for CCA targeted therapy, we investigated further the roles of EBF1 in CCA cell progression. All CCA cell lines had low EBF1 expression [12]. The functional roles of EBF1 in relation to CCA cell progression were studied in KKU-213A cells transfected with control or EBF1-overexpressing vectors. Figure 4A showed the efficiency of EBF1 overexpression in CCA cells using immunofluorescence techniques. After $24 \mathrm{~h}$ of transfection, the EBF1 protein expression levels were higher in the nucleus of EBF1-overexpressing CCA cells than in the control cells.

EBF1 overexpression also affected the lateral migration of CCA cells. An in vitro wound healing assay was performed with CCA cells transfected with EBF1 vector or control vector. Cell migration ability was monitored every $6 \mathrm{~h}$ until the gap closure. The results showed that the overexpression of EBF1 resulted in an apparent decrease in the migration activity of CCA cells as compared with control cells at 12 and $18 \mathrm{~h}$ (Figure 4B), which was confirmed by the quantification of the percentage of migration area
(Figure $4 \mathrm{C}, P<0.05$ ). These results suggest that the overexpression of EBF1 could reduce the migration ability of CCA cells.

The effect of EBF1 overexpression on the proliferation of CCA cells was evaluated using SRB assay. As shown in Figure 4D, cell proliferation was significantly decreased in KKU-213A cells transiently transfected with EBF1 vector as compared with control cells at 48 and $72 \mathrm{~h}$. To investigate the role of EBF1 protein on the invasion ability of KKU-213A cells, we used transwells coated with extracellular matrix. The results indicated that the number of invaded cells that attached to the lower surface of the membrane was significantly lower in EBF1-transfected KKU-213A than that of the control cells $(P<0.05)$, as shown in Figure $4 \mathrm{E}$ and $4 \mathrm{~F}$.

The identification of EBF1-related pathways in CCA, and IL-6-related gene expression in EBF 1-overexpressing CCA cells

RNA sequencing analysis (RNA-seq) was performed from 2 sets of control KKU-213A cells and EBF1-overexprssing KKU-213A cells. Lists of the Entrez gene ID (747 of down-regulated genes and 552 of up-regulated genes) including genes that are significantly changed $(P<0.05$ analyzed by Student's 
t-test, Supplementary Table S3) were subjected to DAVID gene annotation (https://david.ncifcrf.gov) for conducting the pathway enrichment analyses (shown in Table S6 and S7). The Kyoto Encyclopedia of Genes and Genomes (KEGG) analysis demonstrated that EBF1 suppressed "Pathway in Cancer". In the pathway, EBF1 suppressed interleukin 6 (IL-6, $P=0.018$ ), inducible nitric oxide synthase (iNOS or NOS2, $P=0.034$ ) and epidermal growth factor (EGF, $P=0.042$ ). We further confirmed the gene expressions by RT-qPCR, and found that IL-6 (Figure 5B) was significantly down-regulated in EBF1-overexpressing KKU213A cells (Figure 5A), but NOS2 and EGF were not significant different (data not shown). Therefore, IL-6-related genes in CCA were further investigated. IL-6 was previously reported to induce the expressions of COX-2 [34, 35], MMP-9 [36], Oct3/4 [37], SOD2 [38, 39] and CAT [39] in cancer cells. Therefore, we further investigated the expression levels of COX-2, MMP-9, Oct3/4, SOD2 and CAT in the EBF1-overexpressed CCA cells by RT-qPCR. We found that COX-2 (Figure 5C), MMP-9 (Figure 5D), Oct3/4 (Figure 5E), CAT (Figure 5F), SOD2 (Figure 5G) were significantly decreased in EBF1-overexpressing KKU-213A cells compared with their controls.

The expression of CAT and SOD2 are involved in antioxidant system in various cancer cells. In order to elucidate the roles of EBF1 expression in relation to oxidative stress-resistance properties of CCA cancer cells, EBF1-overexpressing KKU-213A cells were exposed to different concentrations of $\mathrm{H}_{2} \mathrm{O}_{2}$. Cell densities were significantly decreased in EBF1-overexpressing KKU-213A cells compared with control cells transfected with empty vector after exposure to high concentrations of $\mathrm{H}_{2} \mathrm{O}_{2}$ (200 and 300 $\mu \mathrm{M})$ for $72 \mathrm{~h}$ (Figure $5 \mathrm{H}$ ). These results suggest that EBF1 could decrease the oxidative stress-resistance property of CCA cells.
A
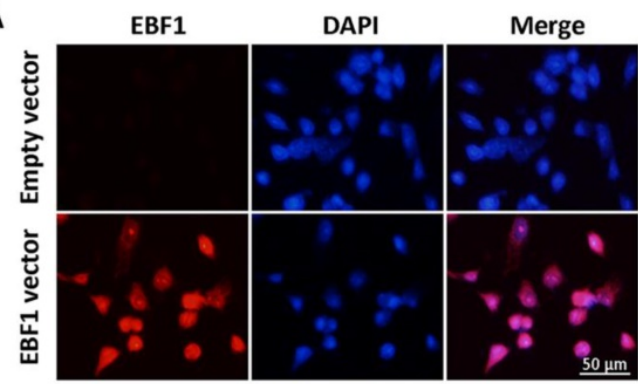

B

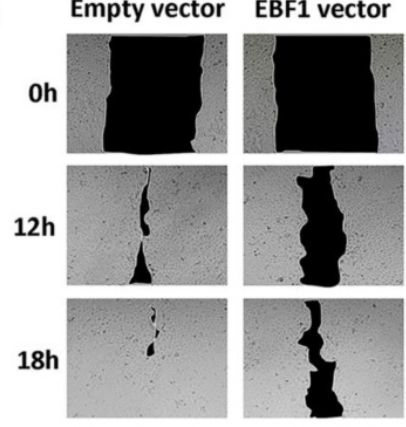

C
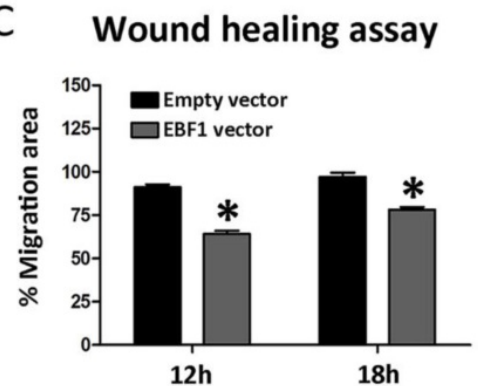

D

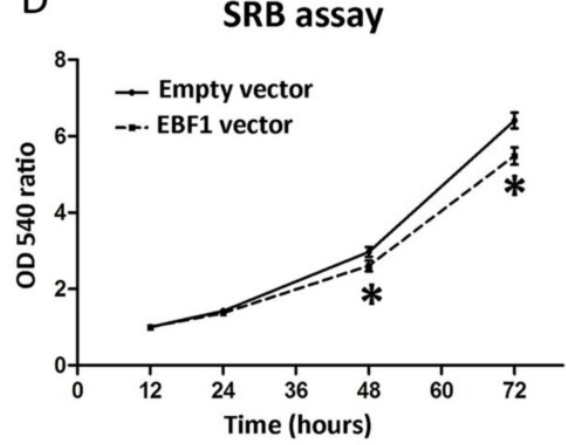

E

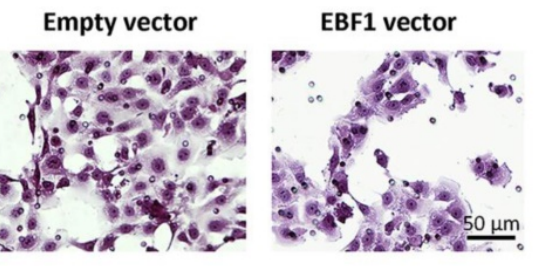

$\mathrm{F}$

Invasion assay

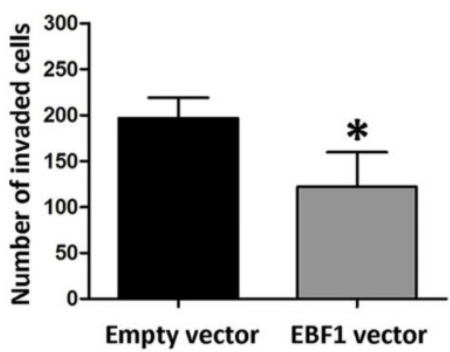

Figure 4. (A) EBF1 protein expression levels in KKU-213A cells transfected with EBF1 vector or with empty vector were measured using immunofluorescence staining. Original magnification is $\times 200$ for all figures. (B) Wound healing assay under a microscope $(\times 10)$, and $(C)$ graphical data indicating the percentage of migration area determined by wound healing assay. (D) Effect of EBF1 overexpression on the proliferation of CCA cells was determined with SRB assay. Proliferation curve of KKU-213A cells transiently transfected with EBF1 vector (dashed line) as compared with empty vector (solid line). (E) Quantification of invading cells was performed by counting six random fields at $\times 200$ under a light microscope. (F) Significant increase in the number of invasive cells in KKU-213A cells transfected with EBF1 vector as compared with control cells. $P$ values are indicated by the asterisk $(*) P<0.05$. 


\section{Discussion}

One of the hallmarks of cancer is the dysregulation of the DNA methylation machinery seeing as aberrant DNA methylation patterns [40]. DNA methylome profiles of breast cancers revealed that EBF1 is an important transcription factor potentially involved in regulation of methylation states [41]. In this study, DNA methylation level at the EBF1 promoter region was significantly higher in CCA tumors compared to NBD tissues using the DNA methylation array analysis. The methylation status of the promoter region of EBF1 gene using MSP analysis confirmed the results obtained from the DNA methylation array analysis. Moreover, MSP analysis revealed the significant correlation between high EBF1 promoter methylation and shorter survival rates of the CCA patients. The DNA methylation rates significantly higher in all CCA cell lines compared with the immortal cholangiocyte cell line, MMNK1. These data suggest that hypermethylation of EBF1 promoter region causes the down-regulation of EBF1 expression in CCA, leading to CCA progression with aggressive clinical outcomes.

The enzymes directly responsible for DNA methylation are DNMTs [42]. Overexpression of DNMTs has been reported in several tumors and ultimately results in the hypermethylation of tumor suppressor genes [43]. 5-Aza-dC is a well-known inhibitor of DNMTs [44]. Several tumor suppressor genes are methylated in cancer cells and their expression can be induced with 5-Aza-dC treatment, leading to the reduction of the progression of tumor growth [45, 46]. Kim and coworkers showed that EBF3, a tumor suppressor gene, was methylated in gastric carcinoma and its function could be restored with 5-Aza-dC treatment [47]. DNMT inhibitors can reduce the progression of some CCA cell lines such as KKU-100, Mz-ChA-1, TFK-1 and QBC939 [48-50]. Our results showed that $5-\mathrm{Aza}-\mathrm{dC}$ treatment induced demethylation of EBF1 promoter region and increased EBF1 mRNA expression. Thus, the DNA methylation of EBF1 promoter by DNMT activation results in the suppression of the EBF1 expression. IL-6/STAT3 signaling pathway induces DNMT1 expression and is
A

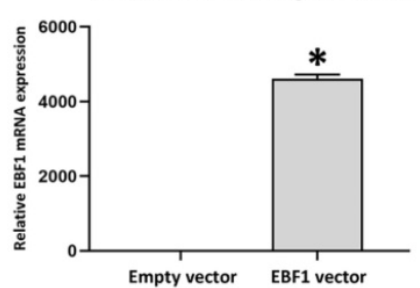

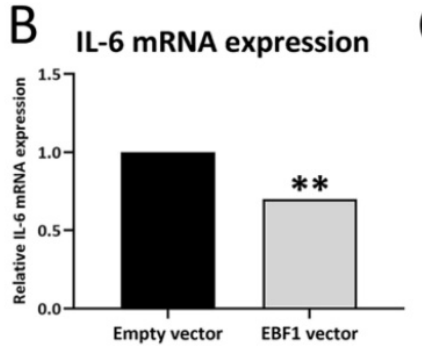
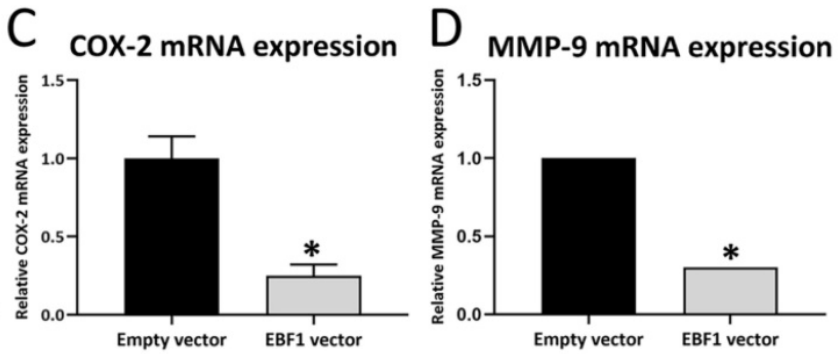

E Oct3/4 mRNA expression

\section{$\mathrm{F}$}
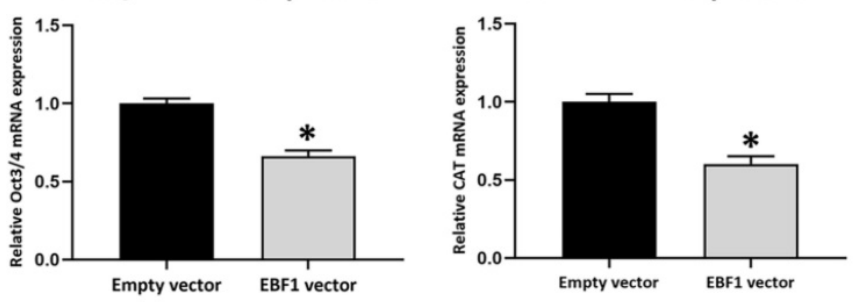

G

SOD2 mRNA expression
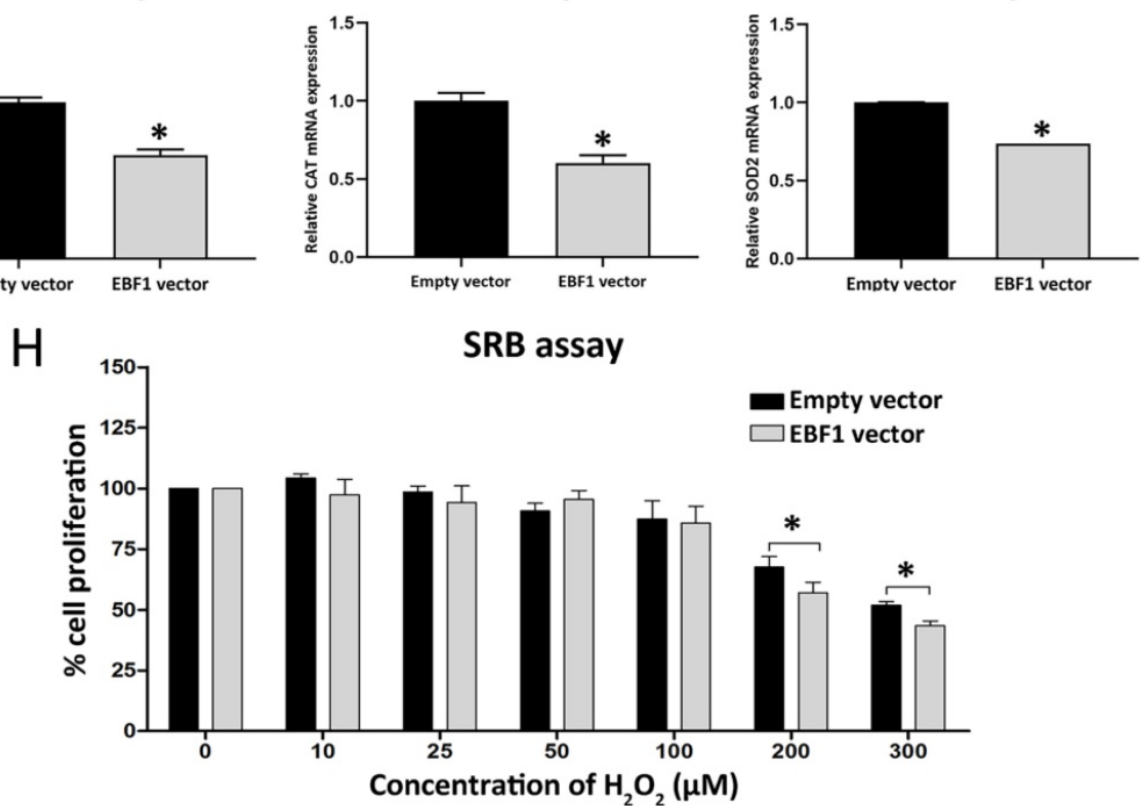

Figure 5. Relative mRNA expression levels of EBF1 (A), IL-6 (B), COX-2 (C), MMP-9 (D), Oct3/4 (E), CAT (F), SOD2 (G) adjusted by $\beta$-actin mRNA expression. (H) The graph represents cell densities of EBFI overexpressing-KKU-213A cells (gray bar) compared with vehicle control (black bar) after exposure to various concentration of $\mathrm{H}_{2} \mathrm{O}_{2}$. $P$ values are indicated by the asterisk, $(*) P<0.05$ and $(* *) P<0.001$. 
involved in epigenetic changes in CCA [51, 52]. In our results, IL-6 was suppressed in EBF1-overexpressing CCA cells, suggesting that promoter hypermethylation of EBF1 in CCA may be activated by IL-6/STAT3 signaling pathway.

Suppression of EBF1 expression increased tumorigenic, stemness and oxidative stress-resistant properties of the cholangiocyte cells, suggesting that downregulation of EBF1 may be involved in the transformation of the cholangiocytes into CCA cells [12]. In the present study, EBF1 expression in CCA cells was induced by the epigenetic therapeutic drug 5-Aza-dC, a DNMT inhibitor, treatment. Then, the functional roles of EBF1 were examined in CCA cells in order to confirm that restored EBF1 expression can suppress tumorigenic, stemness and oxidative stress-resistant properties in the cancer cells, suggesting possible application of epigenetic therapy for CCA treatment. Moreover, overexpression of EBF1 significantly reduced cell proliferation, migration and invasion as compared with the vehicle-treated control cells.
A pro-inflammatory cytokine, IL-6, and an oxidative stress response enzyme, cyclooxygenase 2 (COX-2), are involved in inflammatory processes and cancer progression [36, 51-57]. Chronic inflammation induces not only NF-kB expression, but also its nuclear translocation, leading to activate IL-6 expression and Jak-STAT signaling pathway $[35,58$, 59]. IL-6 expression causes cancer progression via the activations of many IL-6 related pathway such as RAS and MAPK signaling [60,61]. Moreover, COX-2 can induce CCA progression through induction of MMP-9 whereas selective COX-2 inhibitors could inhibit the cancer cell progression [62-64]. The overexpression of MMP-9 can promote cell proliferation through the downregulation of the expression of tumor suppressor genes in renal and glioblastoma cell lines $[65,66]$. Related to cell migration and invasion, epithelial-mesenchymal transition (EMT) is a complex process wherein the epithelial cells acquire the characteristics of invasive mesenchymal cells [67]. MMP-9 is associated with the EMT process and is a well-known marker of EMT [67, 68]. The

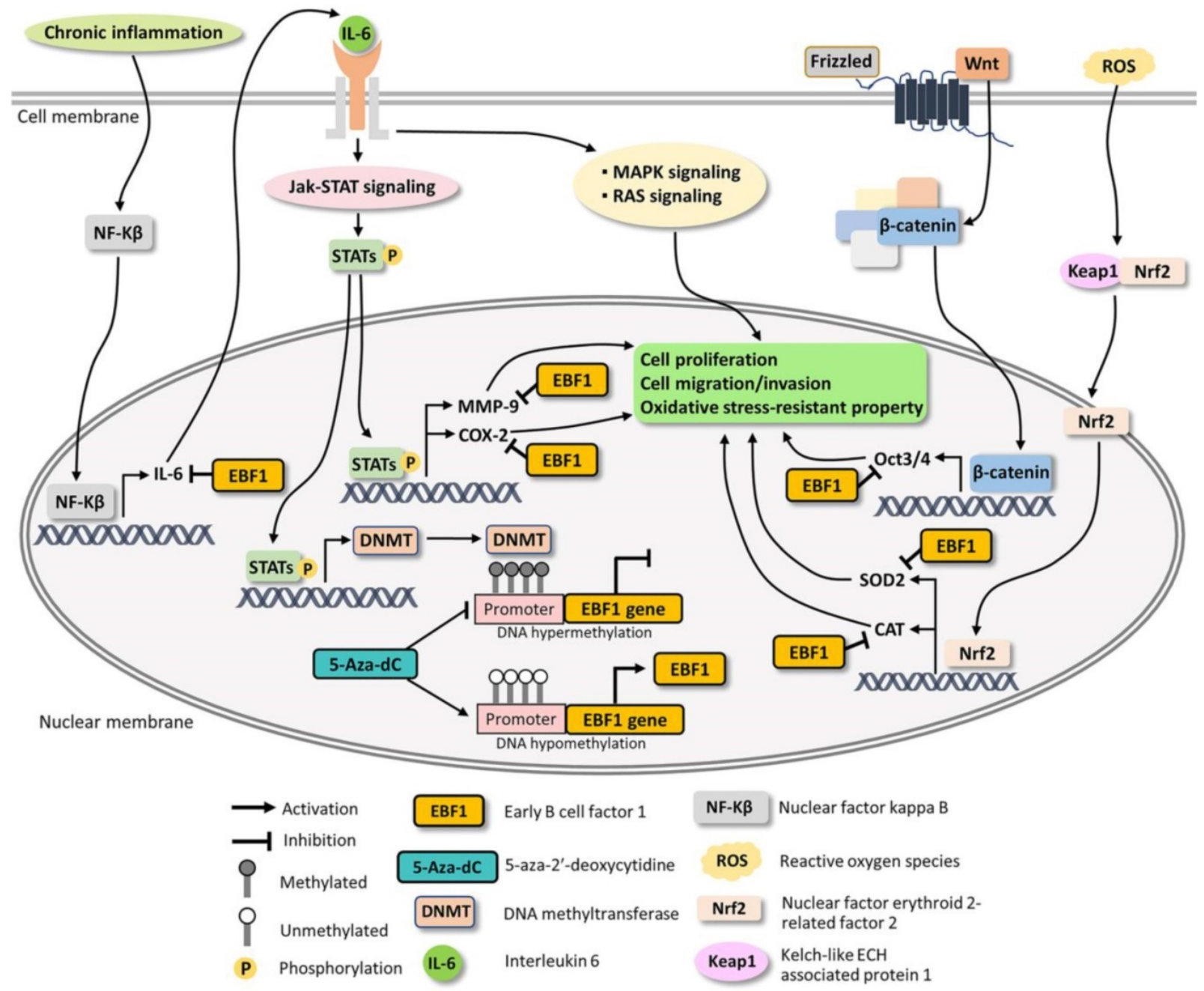

Figure 6. Possible mechanisms underlying EBF1 expression in CCA cells. 
overexpression of MMP-9 contributes to enhance the invasion and migration of CCA cells [69-71]. Our results showed that IL-6, COX-2, MMP-9 as well as RAS and MAPK signaling pathways were significantly reduced in EBF1-overexpressing CCA cells. Taken together, EBF1 suppressed cell proliferation, migration and invasion via down-regulations of IL-6, COX-2 and MMP-9 along with their related pathways such as RAS and MAPK signaling pathways.

EBF1 had been found to induce stem cells differentiation. EBF1 triggers common lymphoid progenitor cells differentiation to pre-mature B cells (pro-B cells) and induced mesenchymal stem cell differentiation to adipocytes and osteocytes [9]. Oct3/4 is expressed in embryonic stem cells, adult stem cells and tumor cells but not in the differentiated cells [72]. Oct3/4 expression was induced by Wnt/ $\beta$-catenin signaling pathway and IL-6/STAT3 signaling pathway [37, 73-75]. Moreover, MMP-9, COX-2 and IL- 6 can promote the induction of stem cell properties of cancer cells [37, 76, 77]. Stem cells protect their genomic stability by maintaining low reactive oxygen species (ROS) via the up-regulation of antioxidant system [78]. Superoxide dismutase 2 (SOD2) expressions is induced by Oct3/4 in the induced pluripotent stem (iPS) cells [79]. SOD and catalase (CAT) are antioxidant genes regulated by Nrf2 transcription factor and are activated by reactive oxygen species (ROS) as well as oxidative stress [80, 81]. In this study, EBF1 overexpression decreased IL-6 related pathways and the expressions of Oct3/4, SOD2 and CAT leading to loss of stemness and oxidative stress-resistant properties of CCA cells.

Based on our findings and literature reviews, the possible mechanisms underlying EBF1 expression in CCA are proposed in Figure 6. Our findings indicate that oxidative stress and promoter hypermethylation are synergistic causes of EBF1 suppression in CCA. EBF1 promoter hypermethylation may be regulated by IL-6/STAT3 signaling pathway. EBF1 inhibits IL-6 expression leading to the inhibitions of Jak-STAT, RAS and MAPK signaling pathways as well as COX-2 and MMP-9 expressions resulting in the inhibition of cancer progression. In addition, EBF1 exhibits tumor suppressive properties in CCA cells through decrease of stemness and oxidative stress-resistant properties via suppressions of Wnt signaling pathway and antioxidants via inhibition of Oct3/4, SOD2 and CAT expression. We therefore conclude that the epigenetic therapy could increase EBF1 expression, which contribute to reduce the tumor progression of the cancer cells.

\section{Abbreviations}

EBF1: Early B cell factor 1; CCA: cholangiocarcinoma; 5-Aza-dC: 5-aza-2'deoxycytidine; MSP: methylation-specific polymerase chain reaction; DNMT: DNA methyltransferase; NBD: normal bile ducts.

\section{Supplementary Material}

Supplementary figures and tables 1, 2, 4-7. http://www.jcancer.org/v12p2673s1.pdf

Supplementary table 3.

http://www.jcancer.org/v12p2673s2.xlsx

\section{Acknowledgements}

We would like to thank the patients and Cholangiocarcinoma Research Institute, Khon Kaen University, Thailand, for providing us with the specimens to conduct experiments in this study. The authors also thank Editage (www.editage.jp) for English language editing. We would like to acknowledge Prof. Yukifumi Nawa, for editing the MS via Publication Clinic KKU, Thailand.

\section{Funding}

This work was supported by the Postgraduate Study Support Grant from Faculty of Medicine, Khon Kaen University to N.A.; Khon Kaen University Research Fund (Grant number 600704) to R.T.; Thailand Research Fund (Grant number RSA6280005) to R.T. This work was partly supported by JSPS KAKENHI Grant Number JP19H03884 (M.M.). The author also thanks the Takeda Science Foundation.

\section{Author Contributions}

N.A. performed the experiments, analyzed the data and wrote the paper with supported from R.T. and M.M. A.J. and C.H.Y. performed and interpreted the genome-wide DNA methylation data. N.S., W.K. and T.C. performed the experiments. P.U. analyzed clinicopathological data. R.T. conceived of the presented idea, interpreted the data, and supervised the project and manuscript preparation. C.S., A.T., W.L., S.P., K.I. and R.K. discussed and analyzed the data. All authors contributed to the final approval of manuscript.

\section{Competing Interests}

The authors have declared that no competing interest exists.

\section{References}

1. Holoch D, Moazed D. RNA-mediated epigenetic regulation of gene expression. Nat Rev Genet. 2015; 16: 71-84.

2. Vaissiere T, Sawan C, Herceg Z. Epigenetic interplay between histone modifications and DNA methylation in gene silencing. Mutat Res. 2008; 659: $40-8$. 
3. Wang G, Weng R, Lan Y, Guo X, Liu Q, Liu X, et al. Synergetic effects of DNA methylation and histone modification during mouse induced pluripotent stem cell generation. Sci Rep. 2017; 7: 39527.

4. Luczak MW, Jagodzinski PP. The role of DNA methylation in cancer development. Folia Histochem Cytobiol. 2006; 44: 143-54.

5. Hitchler MJ, Domann FE. An epigenetic perspective on the free radical theory of development. Free Radic Biol Med. 2007; 43: 1023-36.

6. Xiaofang L, Kun T, Shaoping Y, Zaiqiu W, Hailong S. Correlation between promoter methylation of p14(ARF), TMS1/ASC, and DAPK, and p53 mutation with prognosis in cholangiocarcinoma. World J Surg Oncol. 2012; 10: 5.

7. Fretz JA, Nelson T, Velazquez H, Xi Y, Moeckel GW, Horowitz MC. Early B-cell factor 1 is an essential transcription factor for postnatal glomerular maturation. Kidney Int. 2014; 85: 1091-102.

8. Hesslein DG, Fretz JA, Xi Y, Nelson T, Zhou S, Lorenzo JA, et al. Ebf1-dependent control of the osteoblast and adipocyte lineages. Bone. 2009; 44: $537-46$

9. Liao D. Emerging roles of the EBF family of transcription factors in tumor suppression. Mol Cancer Res. 2009; 7: 1893-901.

10. Mullighan CG, Goorha S, Radtke I, Miller CB, Coustan-Smith E, Dalton JD, et al. Genome-wide analysis of genetic alterations in acute lymphoblastic leukaemia. Nature. 2007; 446: 758-64.

11. Neve RM, Chin K, Fridlyand J, Yeh J, Baehner FL, Fevr T, et al. A collection of breast cancer cell lines for the study of functionally distinct cancer subtypes. Cancer Cell. 2006; 10: 515-27.

12. Armartmuntree N, Murata M, Techasen A, Yongvanit P, Loilome W, Namwat $\mathrm{N}$, et al. Prolonged oxidative stress down-regulates Early B cell factor 1 with inhibition of its tumor suppressive function against cholangiocarcinoma genesis. Redox Biol. 2018; 14: 637-44

13. Jones S, Zhang X, Parsons DW, Lin JC, Leary RJ, Angenendt P, et al. Core signaling pathways in human pancreatic cancers revealed by global genomic analyses. Science. 2008; 321: 1801-6.

14. Chaiprasert T, Armartmuntree N, Techasen A, Sakonsinsiri C, Pinlaor S, Ungarreevittaya $\mathrm{P}$, et al. Roles of Zinc Finger Protein 423 in Proliferation and Invasion of Cholangiocarcinoma through Oxidative Stress. Biomolecules. 2019; 9 .

15. Harder L, Eschenburg G, Zech A, Kriebitzsch N, Otto B, Streichert T, et al. Aberrant ZNF423 impedes B cell differentiation and is linked to adverse outcome of ETV6-RUNX1 negative B precursor acute lymphoblastic leukemia. J Exp Med. 2013; 210: 2289-304.

16. Chung GT, Lung RW, Hui AB, Yip KY, Woo JK, Chow C, et al. Identification of a recurrent transforming UBR5-ZNF423 fusion gene in EBV-associated nasopharyngeal carcinoma. J Pathol. 2013; 231: 158-67.

17. Belarbi Y, Mejhert N, Gao H, Arner P, Ryden M, Kulyte A. MicroRNAs-361-5p and miR-574-5p associate with human adipose morphology and regulate EBF1 expression in white adipose tissue. Mol Cell Endocrinol. 2018; 472: 50-6.

18. Sithithaworn P, Yongvanit P, Duenngai K, Kiatsopit N, Pairojkul C. Roles of liver fluke infection as risk factor for cholangiocarcinoma. J Hepatobiliary Pancreat Sci. 2014; 21: 301-8.

19. Infection with liver flukes (Opisthorchis viverrini, Opisthorchis felineus and Clonorchis sinensis). IARC Monogr Eval Carcinog Risks Hum. 1994; 61: 121-75.

20. Pinlaor S, Yongvanit P, Hiraku Y, Ma N, Semba R, Oikawa S, et al. 8-nitroguanine formation in the liver of hamsters infected with Opisthorchis viverrini. Biochem Biophys Res Commun. 2003; 309: 567-71.

21. Thanan R, Oikawa S, Hiraku Y, Ohnishi S, Ma N, Pinlaor S, et al. Oxidative stress and its significant roles in neurodegenerative diseases and cancer. Int J Mol Sci. 2014; 16: 193-217.

22. Yongvanit P, Pinlaor S, Loilome W. Risk biomarkers for assessment and chemoprevention of liver fluke-associated cholangiocarcinoma. J Hepatobiliary Pancreat Sci. 2014; 21: 309-15.

23. Thanan R, Techasen A, Hou B, Jamnongkan W, Armartmuntree N, Yongvanit $\mathrm{P}$, et al. Development and characterization of a hydrogen peroxide-resistant cholangiocyte cell line: A novel model of oxidative stress-related cholangiocarcinoma genesis. Biochem Biophys Res Commun. 2015; 464: 182-8.

24. Jusakul A, Cutcutache I, Yong CH, Lim JQ, Huang MN, Padmanabhan N, et al. Whole-Genome and Epigenomic Landscapes of Etiologically Distinct Subtypes of Cholangiocarcinoma. Cancer Discov. 2017; 7: 1116-35.

25. Aryee MJ, Jaffe AE, Corrada-Bravo H, Ladd-Acosta C, Feinberg AP, Hansen $\mathrm{KD}$, et al. Minfi: a flexible and comprehensive Bioconductor package for the analysis of Infinium DNA methylation microarrays. Bioinformatics. 2014; 30: $1363-9$

26. Pidsley R, CC YW, Volta M, Lunnon K, Mill J, Schalkwyk LC. A data-driven approach to preprocessing Illumina $450 \mathrm{~K}$ methylation array data. BMC Genomics. 2013; 14: 293.

27. Wang L, Hirayasu K, Ishizawa M, Kobayashi Y. Purification of genomic DNA from human whole blood by isopropanol-fractionation with concentrated Nal and SDS. Nucleic Acids Res. 1994; 22: 1774-5.

28. Sriraksa R, Chaopatchayakul P, Jearanaikoon P, Leelayuwat C, Limpaiboon T. Verification of complete bisulfite modification using Calponin-specific primer sets. Clin Biochem. 2010; 43: 528-30.

29. Tusnady GE, Simon I, Varadi A, Aranyi T. BiSearch: primer-design and search tool for PCR on bisulfite-treated genomes. Nucleic Acids Res. 2005; 33: e9.

30. Aranyi T, Varadi A, Simon I, Tusnady GE. The BiSearch web server. BMC Bioinformatics. 2006; 7: 431
31. Maruyama M, Kobayashi N, Westerman KA, Sakaguchi M, Allain JE, Totsugawa T, et al. Establishment of a highly differentiated immortalized human cholangiocyte cell line with SV40T and hTERT. Transplantation. 2004; 77: 446-51.

32. Sripa B, Seubwai W, Vaeteewoottacharn K, Sawanyawisuth K, Silsirivanit A, Kaewkong W, et al. Functional and genetic characterization of three cell lines derived from a single tumor of an Opisthorchis viverrini-associated cholangiocarcinoma patient. Hum Cell. 2020; 33: 695-708.

33. Crowe AR, Yue W. Semi-quantitative Determination of Protein Expression using Immunohistochemistry Staining and Analysis: An Integrated Protocol. Bio Protoc. 2019; 9.

34. Maihofner C, Charalambous MP, Bhambra U, Lightfoot T, Geisslinger G, Gooderham NJ, et al. Expression of cyclooxygenase-2 parallels expression of interleukin-1beta, interleukin-6 and NF-kappaB in human colorectal cancer. Carcinogenesis. 2003; 24: 665-71

35. Pinlaor S, Tada-Oikawa S, Hiraku Y, Pinlaor P, Ma N, Sithithaworn P, et al. Opisthorchis viverrini antigen induces the expression of Toll-like receptor 2 in macrophage RAW cell line. Int J Parasitol. 2005; 35: 591-6.

36. Sun W, Liu DB, Li WW, Zhang LL, Long GX, Wang JF, et al. Interleukin-6 promotes the migration and invasion of nasopharyngeal carcinoma cell lines and upregulates the expression of MMP-2 and MMP-9. Int J Oncol. 2014; 44: 1551-60.

37. Zhang C, Ma K, Li WY. IL-6 Promotes Cancer Stemness and Oncogenicity in U2OS and MG-63 Osteosarcoma Cells by Upregulating the OPN-STAT3 Pathway. J Cancer. 2019; 10: 6511-25.

38. Hodge DR, Xiao W, Peng B, Cherry JC, Munroe DJ, Farrar WL. Enforced expression of superoxide dismutase 2 /manganese superoxide dismutase disrupts autocrine interleukin-6 stimulation in human multiple myeloma cells and enhances dexamethasone-induced apoptosis. Cancer Res. 2005; 65: 6255-63.

39. Brown $\mathrm{CO}$, Salem $\mathrm{K}$, Wagner $\mathrm{BA}$, Bera $\mathrm{S}$, Singh $\mathrm{N}$, Tiwari $\mathrm{A}$, et al Interleukin-6 counteracts therapy-induced cellular oxidative stress in multiple myeloma by up-regulating manganese superoxide dismutase. Biochem J. 2012; 444: 515-27.

40. Szyf M. The role of DNA hypermethylation and demethylation in cancer and cancer therapy. Curr Oncol. 2008; 15: 72-5.

41. Fernandez-Jimenez N, Sklias A, Ecsedi S, Cahais V, Degli-Esposti D, Jay A, et al. Lowly methylated region analysis identifies EBF1 as a potential epigenetic modifier in breast cancer. Epigenetics. 2017; 12: 964-72.

42. Jin B, Robertson KD. DNA methyltransferases, DNA damage repair, and cancer. Adv Exp Med Biol. 2013; 754: 3-29.

43. Zhang $\mathrm{W}, \mathrm{Xu} \mathrm{J}$. DNA methyltransferases and their roles in tumorigenesis. Biomark Res. 2017; 5: 1

44. Foulks JM, Parnell KM, Nix RN, Chau S, Swierczek K, Saunders M, et al. Epigenetic drug discovery: targeting DNA methyltransferases. J Biomol Screen. 2012; 17: 2-17.

45. Fang JY, Lu J, Chen YX, Yang L. Effects of DNA methylation on expression of tumor suppressor genes and proto-oncogene in human colon cancer cell lines. World J Gastroenterol. 2003; 9: 1976-80.

46. Zuo Y, Song Y, Zhang M, Xu Z, Qian X. Role of PTCH1 gene methylation in gastric carcinogenesis. Oncol Lett. 2014; 8: 679-82

47. Kim J, Min SY, Lee HE, Kim WH. Aberrant DNA methylation and tumor suppressive activity of the EBF3 gene in gastric carcinoma. Int J Cancer. 2012; 130: 817-26.

48. Moolmuang B, Singhirunnusorn P, Ruchirawat M. Effects of 5-Aza-2'-Deoxycytidine, Bromodeoxyuridine, Interferons and Hydrogen Peroxide on Cellular Senescence in Cholangiocarcinoma Cells. Asian Pac J Cancer Prev. 2016; 17: 957-63.

49. Wehbe $\mathrm{H}$, Henson R, Meng F, Mize-Berge J, Patel T. Interleukin-6 contributes to growth in cholangiocarcinoma cells by aberrant promoter methylation and gene expression. Cancer Res. 2006; 66: 10517-24.

50. Wang B, Li H, Yang R, Zhou S, Zou S. Decitabine inhibits the cell growth of cholangiocarcinoma in cultured cell lines and mouse xenografts. Oncol Lett. 2014; 8: 1919-24.

51. Isomoto $\mathrm{H}$. Epigenetic alterations in cholangiocarcinoma-sustained IL-6/STAT3 signaling in cholangio- carcinoma due to SOCS3 epigenetic silencing. Digestion. 2009; 79 Suppl 1: 2-8.

52. Isomoto H, Mott JL, Kobayashi S, Werneburg NW, Bronk SF, Haan S, et al. Sustained IL-6/STAT-3 signaling in cholangiocarcinoma cells due to SOCS-3 epigenetic silencing. Gastroenterology. 2007; 132: 384-96.

53. Johnson C, Han Y, Hughart N, McCarra J, Alpini G, Meng F. Interleukin-6 and its receptor, key players in hepatobiliary inflammation and cancer. Transl Gastrointest Cancer. 2012; 1: 58-70.

54. Luo J, Yan R, He X, He J. Constitutive activation of STAT3 and cyclin D1 overexpression contribute to proliferation, migration and invasion in gastric cancer cells. Am J Transl Res. 2017: 9: 5671-7.

55. Tadlock L, Patel T. Involvement of p38 mitogen-activated protein kinase signaling in transformed growth of a cholangiocarcinoma cell line. Hepatology. 2001; 33: 43-51.

56. Yang $H$, Yin $\mathrm{P}$, Shi $\mathrm{Z}$, Ma $\mathrm{Y}$, Zhao $\mathrm{C}$, Zheng J, et al. Sinomenine, a COX-2 inhibitor, induces cell cycle arrest and inhibits growth of human colon carcinoma cells in vitro and in vivo. Oncol Lett. 2016; 11: 411-8.

57. Yongvanit $\mathrm{P}$, Pinlaor $\mathrm{S}$, Bartsch $\mathrm{H}$. Oxidative and nitrative DNA damage: key events in opisthorchiasis-induced carcinogenesis. Parasitology international. 2012; 61: $130-5$ 
58. McFarland BC, Hong SW, Rajbhandari R, Twitty GB, Jr., Gray GK, Yu H, et al. NF-kappaB-induced IL- 6 ensures STAT3 activation and tumor aggressiveness in glioblastoma. PLoS One. 2013; 8: e78728.

59. Saengboonmee C, Seubwai W, Cha'on U, Sawanyawisuth K, Wongkham S, Wongkham C. Metformin Exerts Antiproliferative and Anti-metastatic Effects Against Cholangiocarcinoma Cells by Targeting STAT3 and NF-kB. Anticancer Res. 2017; 37: 115-23.

60. Kumari N, Dwarakanath BS, Das A, Bhatt AN. Role of interleukin-6 in cancer progression and therapeutic resistance. Tumour Biol. 2016; 37: 11553-72.

61. Ogata A, Chauhan D, Teoh G, Treon SP, Urashima M, Schlossman RL, et al. IL-6 triggers cell growth via the Ras-dependent mitogen-activated protein kinase cascade. J Immunol. 1997; 159: 2212-21.

62. Itatsu K, Sasaki M, Yamaguchi J, Ohira S, Ishikawa A, Ikeda H, et al. Cyclooxygenase-2 is involved in the up-regulation of matrix metalloproteinase- 9 in cholangiocarcinoma induced by tumor necrosis factor-alpha. Am J Pathol. 2009; 174: 829-41.

63. Schmitz KJ, Lang H, Wohlschlaeger J, Reis H, Sotiropoulos GC, Schmid KW, et al. Elevated expression of cyclooxygenase-2 is a negative prognostic factor for overall survival in intrahepatic cholangiocarcinoma. Virchows Arch. 2007; 450: 135-41.

64. Wu T, Leng J, Han C, Demetris AJ. The cyclooxygenase-2 inhibitor celecoxib blocks phosphorylation of Akt and induces apoptosis in human cholangiocarcinoma cells. Mol Cancer Ther. 2004; 3: 299-307.

65. Wang J, Tang C, Yang C, Zheng Q, Hou Y. Tropomyosin-1 Functions as a Tumor Suppressor with Respect to Cell Proliferation, Angiogenesis and Metastasis in Renal Cell Carcinoma. J Cancer. 2019; 10: 2220-8.

66. Xue Q, Cao L, Chen XY, Zhao J, Gao L, Li SZ, et al. High expression of MMP9 in glioma affects cell proliferation and is associated with patient survival rates. Oncol Lett. 2017; 13: 1325-30.

67. Son H, Moon A. Epithelial-mesenchymal Transition and Cell Invasion. Toxicological research. 2010; 26: 245-52.

68. Webb AH, Gao BT, Goldsmith ZK, Irvine AS, Saleh N, Lee RP, et al. Inhibition of MMP-2 and MMP-9 decreases cellular migration, and angiogenesis in in vitro models of retinoblastoma. BMC cancer. 2017; 17: 434.

69. Leelawat K, Sakchinabut S, Narong S, Wannaprasert J. Detection of serum MMP-7 and MMP-9 in cholangiocarcinoma patients: evaluation of diagnostic accuracy. BMC gastroenterology. 2009; 9: 30.

70. Namwat N, Puetkasichonpasutha J, Loilome W, Yongvanit P, Techasen A, Puapairoj A, et al. Downregulation of reversion-inducing-cysteine-rich protein with Kazal motifs (RECK) is associated with enhanced expression of matrix metalloproteinases and cholangiocarcinoma metastases. Journal of gastroenterology. 2011; 46: 664-75.

71. Sun Q, Zhao C, Xia L, He Z, Lu Z, Liu C, et al. High expression of matrix metalloproteinase-9 indicates poor prognosis in human hilar cholangiocarcinoma. International journal of clinical and experimental pathology. 2014; 7: 6157-64.

72. Tai MH, Chang CC, Kiupel M, Webster JD, Olson LK, Trosko JE. Oct4 expression in adult human stem cells: evidence in support of the stem cell theory of carcinogenesis. Carcinogenesis. 2005; 26: 495-502.

73. Bisson I, Prowse DM. WNT signaling regulates self-renewal and differentiation of prostate cancer cells with stem cell characteristics. Cell Res. 2009; 19: 683-97.

74. Li J, Li J, Chen B. Oct4 was a novel target of Wnt signaling pathway. Mol Cell Biochem. 2012; 362: 233-40.

75. Merrill BJ. Wnt pathway regulation of embryonic stem cell self-renewal. Cold Spring Harb Perspect Biol. 2012; 4: a007971.

76. Moirangthem A, Bondhopadhyay B, Mukherjee M, Bandyopadhyay A, Mukherjee N, Konar K, et al. Simultaneous knockdown of uPA and MMP9 can reduce breast cancer progression by increasing cell-cell adhesion and modulating EMT genes. Sci Rep. 2016; 6: 21903.

77. Majumder M, Xin X, Liu L, Tutunea-Fatan E, Rodriguez-Torres M, Vincent K, et al. COX-2 Induces Breast Cancer Stem Cells via EP4/PI3K/AKT/NOTCH/ WNT Axis. Stem Cells. 2016; 34: 2290-305.

78. Chaudhari P, Ye Z, Jang YY. Roles of reactive oxygen species in the fate of stem cells. Antioxid Redox Signal. 2014; 20: 1881-90.

79. Solari C, Vazquez Echegaray C, Cosentino MS, Petrone MV, Waisman A, Luzzani C, et al. Manganese Superoxide Dismutase Gene Expression Is Induced by Nanog and Oct4, Essential Pluripotent Stem Cells' Transcription Factors. PLoS One. 2015; 10: e0144336.

80. Kim EK, Jang M, Song MJ, Kim D, Kim Y, Jang HH. Redox-Mediated Mechanism of Chemoresistance in Cancer Cells. Antioxidants (Basel). 2019; 8.

81. Liu X, Ward $\mathrm{K}$, Xavier $\mathrm{C}$, Jann J, Clark AF, Pang IH, et al. The novel triterpenoid RTA 408 protects human retinal pigment epithelial cells against $\mathrm{H} 2 \mathrm{O} 2$-induced cell injury via NF-E2-related factor 2 (Nrf2) activation. Redox Biol. 2016; 8: 98-109. 